\title{
Uji Antioksidan Belimbing Wuluh dan Ampas Nanas Terhadap Kualitas Minyak Goreng Habis Pakai
}

\author{
Siti Mardiyah ${ }^{1}$ \\ 1) Prodi D3 Teknologi Laboratorium Medis, Fakultas Ilmu Kesehatan, Universitas Muhammadiyah \\ Surabaya \\ Sitimardiyahfix2@gmail.com
}

Tanggal Submit:
22 Februari 2021
Tanggal Review:
16 Maret 2021
Tanggal Publish
Online: 18 Juni 2021

Tanggal Submit:

\begin{abstract}
Used Cooking Oil is oil produced from frying residue and is carcinogenic because it causes oxidation, hydrolysis, and polymerization to produce toxic peroxides and free fatty acids that are difficult for the body to digest. Measurement of oil quality can be measured through 3 parameters, namely, the peroxide number, the acid number and the oil color. Efforts to control the quality of cooking oil are the addition of natural antioxidants, starch wuluh and pineapple pulp. Starfruit contains flavonoids, terpenoids, phenols and pectins as well as Vitamins $\mathrm{C}$ and $\mathrm{A}$ which can absorb free radicals in oil. Meanwhile, pineapple pulp contains high levels of vitamin C, flavonoids and polyphenols which can eat free radicals. This Research aims to determine the differences in the antioxidant power of starfruit and pineapple pulp to maintain the quality of used cooking oil. This research is experimental, which will study the antioxidant power of starfruit and pineapple pulp at the acid number, peroxidant and color intensity of used cooking oil. 3 grams of dry starfruit and 0.4 grams of dried pineapple pulp are added to each pad $100 \mathrm{~mL}$ of used cooking oil. The application of starfruit and pineapple pulp in used cooking oil had a significant effect on the 3 oil quality parameters, namely the acid number, the peroxide number and the oil color intensity, with a significance value of $\mathrm{P}<0.05$. This is because the antioxidant content and composition of the two ingredients are different. Wuluh starfruit in the addition of 3 grams provides a fairly large antioxidant effect, while pineapple pulp at a concentration of 0.4 grams has shown antioxidant power so a higher concentration is needed to produce optimal antioxidant power.
\end{abstract}

Keywords : Antioxidants, Starfruit, Pineapple Dregs

\section{PENDAHULUAN}

Minyak terdapat pada hampir semua bahan pangan dengan kandungan yang berbeda-beda Pemanfaatan minyak goreng dapat ditemui industri keripik dan industri makanan lain yang menggunakan minyak goreng untuk mengolah produksinya (Syabanu \& Cahyaratri, 2009). Minyak goreng merupakan bahan pangan yang berperan penting dalam gizi karena merupakan 
sumber energi, cita rasa, serta pelarut vitamin A, D, E, dan K Minyak goreng memiliki sifat fisik yaitu berwarna kuning keemasan dan transparan (Dewintasari, 2018). Minyak goreng yang telah digunakan berulang kali disebut juga minyak habis pakai.

Minyak habis pakai merupakan minyak yang dihasilkan dari sisa penggorengan kebutuhan rumah tangga baik dari minyak kelapa maupun minyak sawit dan bersifat karsinogenik, yang terjadi selama proses penggorengan (Anonim, 2011a). Minyak habis pakai menyebabkan minyak menjadi berasap atau berbusa pada saat penggorengan, meninggalkan warna cokelat (Hambali, 2007). Hal tersebut dapat mempengaruhi kesehatan seseorang, disamping itu makanan hasil gorengannya tidak seenak menggunakan minyak segar.

Menurut Wijana S (2005), selama penggorengan, minyak goreng mengalami pemanasan pada suhu tinggi $\pm 170-180^{\circ} \mathrm{C}$ dalam waktu yaang cukup lama. Hal ini akan menyebabkan terjadinya oksidasi, hidrolisis, dan polimerisasi. Proses tersebut menghasilkan peroksida yang bersifat toksik dan asam lemak bebas yang sukar dicerna oleh tubuh. Parameter kerusakan minyak dapat ditunjukkan dengan angka peroksida dan asam lemak bebas (Lokmanto, 2010). Oleh karena itu pengukuran kualitas minyak dapat diukur melalui 3 parameter yakni, Bilangan peroksida, bilangan asam dan warna minyak

Bilangan peroksida adalah nilai terpenting untuk menentukan derajat kerusakan pada minyak atau lemak. Asam lemak bebas dapat mengikat oksigen pada ikatan rangkapnya sehingga membentuk peroksida (Utari dkk, 2015). Jumlah peroksida pada bahan pangan dan minyak goreng yang melebihi standar mutu akan memberikan sifat racun yang menimbulkan gejala diare, kelambatan pertumbuhan, perbesaran organ, deposit lemak tidak normal, kontrol tidak sempurna pada pusat syaraf, gatal pada tenggorokan, iritasi saluran pencernaan, kanker, mempersingkat umur (Ketaren, 2012).

Bilangan asam menunjukkan banyaknya asam lemak bebas dalam minyak yang dinyatakan dengan $\mathrm{mg}$ basa per 1 gram minyak. Bilangan ini menunjukkan banyaknya asam lemak bebas yang ada dalam minyak akibat terjadi reaksi hidrolisis pada minyak terutama pada saat pengolahan (Rohman, 2007 ; Ketaren, 2012).

Warna minyak yang sudah lama digunakan sebagai indikator fisik dalam melihat kerusakan minyak. Pengujian warna untuk menentukan kualitas minyak goreng dipengaruhi oleh batch dari minyak, jumlah dan tipe dari makanan yang digoreng, suhu 
dan tipe penggorengan, serta jarak estimasi visual dari digunakan warna yang tidak terlihat lampu (Blumethal, 1996). Penentuan warna dengan menggunakan spektrofotometer dengan minyak segar sebagai referensi (blanko). Kenaikan nilai absorbansi minyak memperlihatkan warna minyak semakin gelap yang disebabkan oleh adanya kenaikan senyawa-senyawa hasildegradasi minyak (Przybylski, 2000).

Penggunaan minyak Habis pakai dalam rumah tangga lebih dari dua kali masih banyak ditemui dalam kesehariannya dan belum tahu akan kerugian dan bahaya yang ditimbulkan penggunaan minyak goreng yang dipanaskan berulang-ulang, akan menyebabkan proses destruksi minyak akan bertambah cepat, hal ini disebabkan meningkatnya kadar peroksida pada tahap pendinginan yang akan mengalami dekomposisi jika minyak tersebut dipanaskan kembali. Minyak yang dipakai lebih dari dua kali dapat berpotensi untuk menimbulkan penyakit kanker, kerusakan organ-organ penting lainnya serta dapat menimbulkan penyakit degeratif seperti jantung koroner, diabetes dan stroke (Sitepoe, 2008). Melihat fenomena tersebut, maka perlu adanya alternatif pengolahan minyak habis pakai.
Alternatif untuk peningkatan kualitas minyak goreng adalah dengan penambahan antioksidan. Antioksidan adalah zat yang dapat mencegah terjadinya reaksi oksidasi radikal bebas dalam oksidasi lemak dan memperkecil terjadinya proses kerusakan pada minyak. Peningkatan kualitas minyak goreng habis pakai dapat dilaukan dengan penambahan antioksidan alami diperoleh langsung dari alam. Pada umumnya antioksidan alami merupakan bahan alam yang mengandung senyawa dari golongan Flavonoid, Terpenoid, Fenol, tanin dan sebagainya. Salah satunya yaitu belimbing wuluh (Rohman, 2013).

Belimbing wuluh (Averrhoa bilimbi L.) merupakan salah satu jenis buah tropis yang berbuah sepanjang tahun yang kaya akan kandungan antioksidan namun pemanfaatannya belum optimal (Hertanto, 2012 ; Rahayu, 2013). Zakaria et al. (2007) melaporkan bahwa buah belimbing wuluh mengandung golongan senyawa oksalat, flavonoid, terpenoid, fenol, dan pektin. Belimbing wuluh juga mengandung senyawa kimia berupa glikosida, protein, lemak, kalsium, fosfor, besi, vitamin B1, vitamin C, vitamin A, saponin, tanin (Wijayakusuma \& Dalimartha, 2006 ; Ikram et al., 2009). 
Terpenoid dan vitamin A merupakan antioksidan larut dalam minyak, sehingga dapat digunakan untuk mengabsorbsi radikal bebas yang terdapat dalam minyak. Senyawa flavonoid merupakan antioksidan yang berperan memperlambat terjadinya oksidasi yang berakibat proses terurainya asam-asam lemak berangsur lebih lambat (Wijayakusuma \& Dalimartha, 2006). Tanin merupakan himpunan polihidroksi fenol yang dapat dibedakan dari fenol-fenol lain karena kemampuannya mengendapkan protein. Senyawa ini mempunyai aktivitas antioksidan menghambat pertumbuhan tumor (Anggraini N \& Saputra, 2016).

Belimbing wuluh memiliki kandungan fenol sebanyak $1261,63 \pm 31,41 \mathrm{mg}$ GAE/100 g dan memiliki nilai aktivitas antioksidan sebesar 91,89\% $\pm 0,01 \%$ (Ikram et al., 2009). Berdasarkan hasil pemeriksaan yang dilakukan Patil, et al. (2010),

Senyawa flavonoid juga ditemukan dalam buah nanas. Bagian utama yang bernilai ekonomi penting dari tanaman nanas adalah buahnya. Buah nanas memiliki kandungan air 90\% dan kaya akan kalium, kalsium, iodium, sulfur, dan khlor. Selain itu juga kaya asam, vitamin A, vitamin C, vitamin B, kalori, protein, lemak, enzim bromelin, serta flavonoid, dan polifenol (Kurniawan, 2008). Hasil pengolahan secara ekonomis buah nanas menghasilkan ampas sebagai sampah yang dibuang. Sebagai bagian dari buah nanas, ampas Nanas masih mengandung zat anti oksidan yang dapat dimanfaatkan untuk memperthankan kualitas minyak habis pakai.

Kemampuan ampas nanas sebagai antioksidan semakin lengkap karena buah ini mengandung banyak vitamin $\mathrm{C}$, flavonoid dan polifenol yang cukup tinggi (Lingga, 2012). Polifenol merupakan senyawa turunan fenol yang mempunyai aktivitas sebagai antioksidan. Fungsi polifenol sebagai penangkap dan pengikat radikal bebas dari ion-ion logam yang rusak.

Hasil penelitian Puspitasani,2017 mengenai pemanfaatan ampas nanas (Ananas comosus L. merr) dalam pengolahan minyak Habis pakai menjadi minyak segar dapat menyimpulan bahwa adanya pengaruh pemberian ampas nanas (Ananas comosus L. merr) dalam pengolahan minyak Habis pakai menjadi minyak segar. Dengan kosentrasi yang efektif pada bilangan peroksida, bilangan asam, dan absorbansi warna adalah $0,4 \%$

Sedangkan hasil penelitian yang dilakukan oleh Febriani, 2019 menunjukkan adanya pengaruh pemberian belimbing wuluh (Averrhoa bilimbi L.) terhadap kualitas minyak 
curah dengan konsentrasi efektif pada penambahan 3 gram belimbing wuluh pada $100 \mathrm{~mL}$ minyak goreng bekas pakai.

Sejauh ini belum dilakukan penelitian mengenai perbedaan efektifitas ampas nans dan belimbing wuluh untuk mengendalikan kualitas minyak habis pakai. Hal ini perlu dilakukan untuk menentukan bahan antioksidan alami yang paling efektif, sehingga memudahkan dalam pemilihan bahan yang akan digunaan untuk mengendalikan mutu minyak. Langkah ini merupakan salah satu upaya untuk menekan aspek ekomonis pengendalian kualiatas minyak, sehingga akan ditemuan bahan alami yang lebih murah dan praktis untuk dimanfaaatan sebagai antioksidan alami.

Berdasarkan uraian diatas, Penelitian ini bertujuan untuk mengetahui perbedaan daya antioksidan belimbing wuluh dan ampas nanas untuk mempertahankan kualitas minyak goreng habis pakai.

\section{METODE PENELITIAN}

Jenis penelitian ini adalah eksperimental. Populasi dan sampel penelitian adalah minyak goremg habis pakai dengan total sampel 8. Variabel Penelitian terdiri atas variabel bebas, variabel terikat, dan variabel kontrol. Variabel bebas adalah pemberian ampas nanas dengan konsneyrasi $(0,4 \%)$ dan belimbing wuluh dengan konsenrasi 0,3 $\%$. Sedangkan variabel terikat adalah kualitas minyak habis pakat yang diukur dengan 3 parameter yaitu bilangan asam, bilangan peroksida, dan absorbansi warna. Data hasil bilangan asam, bilangan peroksida, dan absorbansi selanjutnya ditabulasikan dan dilakukan analisis data uji t- bebas dengan tingkat kesalahan 0,05 .

Penyiapan minyak goreng habis pakai yang diperlakukan dengan delimbing wuluh dilakukan sebagai berikut : Belimbing wuluh yang sudah dicuci bersih dipotong-potong dengan ukuran kecil-kecil. Lalu keringkan supaya kandungan air yang terdapat didalamnya habis. Kemudian minyak goreng habis pakai diberi belimbing wuluh yang sudah dikeringkan dengan berat 3 gram pada $100 \mathrm{ml}$ minyak dan didiamkan selama 24 jam.

Sedangkan minyak goreng habis pakai yang diperalkukan dengan ampas nanas diberikan perlakuan seabgai berikut : buah nansa yang sudah dcuci dan dikupas, kenudian di blender dan diperas untuk diambil ampasnya dan dikeringan. Kemudian ditimbang 4 gram ampas nanas dan dimsukkan kedalam $100 \mathrm{~mL}$ minyak goreng habis pakai, selanjutnya didiamkan selama 24 jam. 


\section{Penetapan Bilangan Asam}

Menimbang kurang lebih 20 gram minyak yang sudah diperlakukan dengan belimbing wuluh dan ampas nanas kedalam erlenmeyer $250 \mathrm{ml}$. Kemudian ditambahkan $50 \mathrm{ml}$ alkohol $96 \%$ yang telah dinetralkan. Selanjutkan dpanaskan sampai mendidih kemudian didinginkan. Setelah dingin sampel dititrasi dengan larutan standar $\mathrm{NaOH} 0,1 \mathrm{~N}$ dengan 3 tetes indikator PP 1\% tepat sampai warna merah jambu muda.

\section{Penetapan Bilangan Peroksida}

Menimbang kurang lebih 25 gram minyak yang sudah diperlakukan dengan belimbing wuluh dan ampas nanas dalam erlenmeyer tutup asah 250 ml.Ditambahkan $30 \mathrm{ml}$ larutan asam asetat-klorofom (3:2) sambil digoyang sampai bahan terlarut sempurna.Selanjutnya ditambahkan 0,5 ml larutan KI jenuh dan didiamkan selama 1 menit dengan kadang-kadang digoyang. Kemudian ditambahkan $30 \mathrm{ml}$ aquadest. Kemudian dititrasi dengan $\mathrm{Na} 2 \mathrm{~S} 2 \mathrm{O} 30,1 \mathrm{~N}$ sampai warna kuning muda, lalu tambahkan dengan indikator amylum $1 \%$ sebanyak $0,5 \mathrm{ml}$, titrasi lagi sampai warna biru tepat hilang.

\section{Pemeriksaan Warna Minyak}

\section{Goreng.}

Intensitas warna adalah analisis warna minyak yang dilihat absorbansi dan panjang gelombang sesuai warna minyak menggunakan spektrofotometer yang diukur pada panjang gelombang 470 nm ((Przybylski, 2000 dalam AR Ariyani, 2012 dan Sari, 2017).

\section{HASIL PENELITIAN}

Hasil pemeriksaan bilangan asam pada minyak goreng habis pakai yang diperlakukan dengan belimbng wuluh dan ampas nanas dapat disajikan pada tabel berikut ini:

Tabel 4.1 Hasil pemeriksaan bilangan asam pada minyak goreng habis pakai dengan penambahan belimbing wuluh dan ampas nanas

\begin{tabular}{|c|c|c|}
\hline \multirow{2}{*}{$\begin{array}{c}\text { Kode } \\
\text { Sampel }\end{array}$} & \multicolumn{2}{|c|}{$\begin{array}{l}\text { Bilangan Asam Minyak Goreng Habis } \\
\text { Pakai }\end{array}$} \\
\hline & $\begin{array}{c}3 \text { gram } \\
\text { belimbing wuluh } \\
\text { dalam } 100 \mathrm{~mL} \\
\text { minyak }\end{array}$ & $\begin{array}{c}\text { 0,4 gram } \\
\text { ampas nanas } \\
\text { dalam } 100 \mathrm{~mL} \\
\text { minyak } \\
\end{array}$ \\
\hline 1 & 0,0808 & 0,380 \\
\hline 2 & 0,1010 & 0,493 \\
\hline 3 & 0,1212 & 0,309 \\
\hline 4 & 0,1414 & 0,450 \\
\hline 5 & 0,0606 & 0,380 \\
\hline 6 & 0,0404 & 0,369 \\
\hline$\Sigma$ & 0,5454 & 2,381 \\
\hline $\mathbf{X}$ & 0,0909 & 0,396833 \\
\hline SD & 0,06608 & 0,065009 \\
\hline
\end{tabular}

Rerata bilangan asam pada kedua perlakuan dapat disajikan dalam bentuk diagram balok untuk memudahkan pembacan seperti pada gambar 1. 


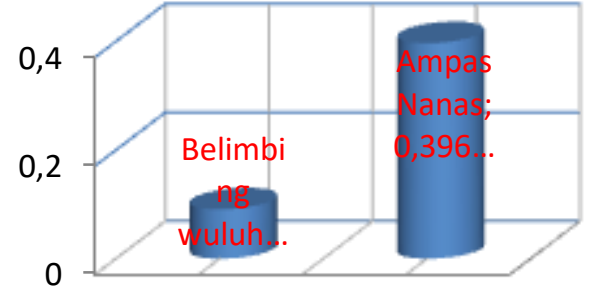

Gambar 1. Diagram balok nilai rerata bilangan asam

Hasil pemeriksaan bilangan peroksida pada minyak goreng habis pakai yang diperlakukan dengan belimbng wuluh dan ampas nanas dapat disajikan pada tabel berikut ini:

Tabel 4.2 Hasil pemeriksaan bilangan peroksida pada minyak goreng habis pakai dengan penambahan belimbing wuluh dan ampas nanas

\begin{tabular}{|c|c|c|}
\hline \multirow{2}{*}{$\begin{array}{c}\text { Kode } \\
\text { Sampel }\end{array}$} & \multicolumn{2}{|c|}{$\begin{array}{c}\text { Bilangan Peroksida Minyak Goreng habis } \\
\text { pakai }\end{array}$} \\
\cline { 2 - 3 } & $\begin{array}{c}\text { 3 gram belimbing } \\
\text { wuluh dalam 100 } \\
\text { mL minyak }\end{array}$ & $\begin{array}{c}\mathbf{0 , 4} \text { gram ampas } \\
\text { nanas dalam 100 } \\
\text { mL minyak }\end{array}$ \\
\hline 1 & 8,466 & 10,584 \\
\hline 2 & 9,2352 & 10,976 \\
\hline 3 & 8,8504 & 9,800 \\
\hline 4 & 7,696 & 9,408 \\
\hline 5 & 8,0808 & 10,584 \\
\hline 6 & 9,62 & 10,976 \\
\hline $\mathbf{2}$ & 51,9484 & $\mathbf{6 2 , 3 2 8}$ \\
\hline $\mathbf{X}$ & $\mathbf{8 , 6 5 8 1}$ & $\mathbf{1 0 , 3 8 8}$ \\
\hline SD & $\mathbf{0 , 0 6 6 0 8}$ & $\mathbf{0 , 6 4 4 1 2 2}$ \\
\hline
\end{tabular}

Rerata bilangan peroksida pada kedua perlakuan dapat disajikan dalam bentuk diagram balok untuk memudahkan pembacan seperti pada gambar 2.

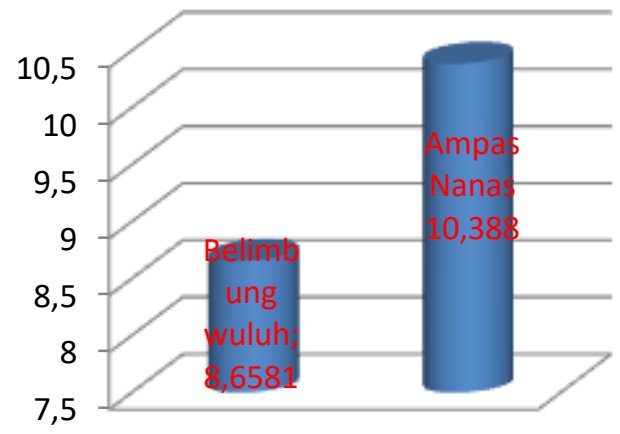

Gambar 2. Diagram balok nilai rerata bilangan perosida

Hasil pengukuran absorbansi pada minyak goreng habis pakai yang diperlakukan dengan belimbng wuluh dan ampas nanas diukur pada $470 \mathrm{~nm}$ dapat disajikan pada tabel berikut ini :

Tabel 4.3 Hasil absorbansi warna pada minyak goreng habis pakai dengan penambahan belimbing wuluh dan ampas nanas

\begin{tabular}{|c|c|c|}
\hline \multirow{2}{*}{$\begin{array}{c}\text { Kode } \\
\text { Sampel }\end{array}$} & \multicolumn{2}{|c|}{$\begin{array}{c}\text { Absorbansi warna minyak } \\
\text { goreng habis pakai }\end{array}$} \\
\cline { 2 - 3 } & $\begin{array}{c}\text { 3 gram } \\
\text { belimbing wuluh } \\
\text { dalam 100 mL } \\
\text { minyak }\end{array}$ & $\begin{array}{c}\text { 0,4 gram } \\
\text { Ampas nanas } \\
\text { dalam 100 } \\
\text { mL minyak }\end{array}$ \\
\hline 1 & 0,188 & 0,734 \\
\hline 2 & 0,254 & 0,783 \\
\hline 3 & 0,247 & 0,820 \\
\hline 4 & 0,248 & 0,723 \\
\hline 5 & 0,288 & 0,734 \\
\hline 6 & 0,291 & 0,783 \\
\hline $\mathbf{\Sigma}$ & $\mathbf{1 , 5 1 6}$ & $\mathbf{4 , 5 7 7}$ \\
\hline $\mathbf{X}$ & $\mathbf{0 , 2 5 2 7}$ & $\mathbf{0 , 7 6 2 8 3 3}$ \\
\hline SD & $\mathbf{0 , 0 3 7 3 0}$ & $\mathbf{0 , 0 3 8 2 9 1}$ \\
\hline
\end{tabular}

Rerata bilangan peroksida pada kedua perlakuan dapat disajikan dalam bentuk diagram balok untuk memudahkan pembacan seperti pada gambar 3. 


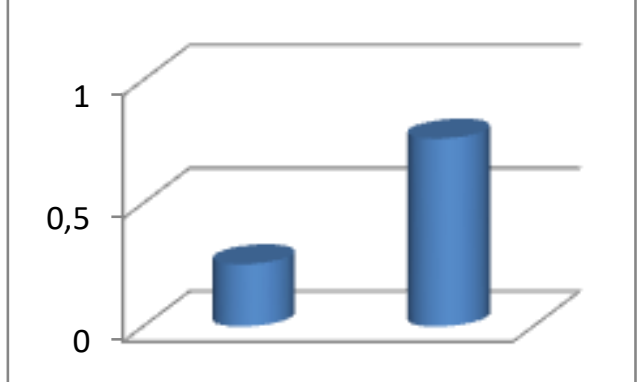

Gambar 2. Diagram balok nilai rerata bilangan asam

\section{Analisis Data}

Data parameter ukulitas minya goreng yang sudah ditabulasikan kemudian dianalisis menggunakan uji SPSS, yaitu uji normalitas untuk mengetahui data tersebut berdistribusi normal pada setiap parameter menggunakan uji $\mathrm{F}$ dengan ketentuan data terdistribusi normal jika F hitung < F Tabel. Hasil uji normalitas pada minyak curah setiap parameter dapat dilihat pada tabel dibawah ini :

Tabel 4.4 Rangkuman Hasil Uji Normalitas

\begin{tabular}{|l|c|c|l|}
\hline Parameter & $\begin{array}{c}\text { Nilai F } \\
\text { Hitung }\end{array}$ & $\begin{array}{c}\text { Nilai } \\
\text { F } \\
\text { Tabel }\end{array}$ & Keterangan \\
\hline $\begin{array}{l}\text { Bilangan } \\
\text { Asam }\end{array}$ & 2,959 & 5,14 & $\begin{array}{c}\text { Berdistribusi } \\
\text { Normal }\end{array}$ \\
\hline $\begin{array}{l}\text { Bilangan } \\
\text { Peroksida }\end{array}$ & 0,800 & 5,14 & $\begin{array}{c}\text { Berdistribusi } \\
\text { Normal }\end{array}$ \\
\hline $\begin{array}{l}\text { Absorbansi } \\
\text { Warna }\end{array}$ & 1,054 & 5,14 & $\begin{array}{c}\text { Berdistribusi } \\
\text { Normal }\end{array}$ \\
\hline
\end{tabular}

Jika signifikan $\mathrm{F}$ hitung $<\mathrm{F}$

Tabel, data hasil dinyatakan berdistribusi normal. Selanjutnya, untuk menentukan pengaruh pemberian belimbing wuluh dan Ampas nanas terhadap kualitas minyak curah menggunakan Uji $\mathrm{T}$ bebas. Hasil uji $\mathrm{T}$ bebas pada minyak curah setiap parameter dapat dilihat pada tabel dibawah ini :

Tabel 4.4 Rangkuman Hasil Uji T bebas

\begin{tabular}{|l|c|c|}
\hline Parameter & $\begin{array}{c}\text { Nilai } \\
\text { Signifikan }\end{array}$ & Keterangan \\
\hline $\begin{array}{l}\text { Bilangan } \\
\text { Asam }\end{array}$ & 0,0000 & Signifikan \\
\hline $\begin{array}{l}\text { Bilangan } \\
\text { Peroksida }\end{array}$ & 0,0002 & Signifikan \\
\hline $\begin{array}{l}\text { Absorbansi } \\
\text { Warna }\end{array}$ & 0,0000 & Signifikan \\
\hline
\end{tabular}

Berdasarkan tabel 4.4 dapat dilihat bahwa ada pengaruh pemberian belimbing wuluh dan ampas nanas pada minyak goreng bekas pakai terhadap kualitas minyak curah yang ditunjukkan dengan P (sig) 0,000; 0,0002, 0,0000 dimana $\mathrm{P}(\mathrm{sig})<0,05$. Jadi, Hipotesis $\left(\mathrm{H}_{1}\right)$ diterima artinya ada perbedaan signifikan antara penambahan belimbing wuluh dan ampas nanas terhadap bilangan asam, bilangan peroksidan dan intensitas warna pada minyak goreng bekas pakai. 


\section{PEMBAHASAN}

Hasil uji $\mathrm{T}$ bebas menunjukkan bahwa pemberian belimbing wuluh dan ampas nanas pada minyak goreng bekas pakai memberikan pengaruh signifikan terhadap yang 3 parameter kualitas minyak yakni bilangan asam, bilangan peroksida dan intensitas warna minyak. Hal ini terjadi karena kandungan zat anti oksidan pada belimbing wuluh dan ampas nanas berbeda-beda. Walaupun keduanya memiliki anti oksidan yang sama seperti flavonoid, namun kadar Flavonoid pada belimbing wuluh dan ampas nanas tidak sama. Semakin besar kadarnya maka daya antioksidannya akan semakin besar. Flavonoid merupakan salah satu senyawa golongan fenol alam yang terbesar yang diketahui memiliki sifat sebagai penangkap radikal bebas, penghambat enzim hidrolisis dan oksidatif, dan bekerja sebagai anti inflamasi. Flavonoid dapat bekerja sebagai antioksidan alami, dimana antioksidan alami tidak hanya menghambat reaksi kimia oksidasi yang dapat merusak makromolekul dan menimbulkan berbagai masalah kesehatan, namun juga menambahkan kandungan nutrisi pada minyak goreng (Bera, 2005 dalam Ayucitra, 2011 dan Haris, 2011).

Hal lain yang menyebabkan adanya perbedaan pengaruh daya natioksidan belimbung wuluh dan ampas nanas disebabkan karena perebedaan jenis antioksidan selain Flavonoid. Antioksidan pada belimbing wuluh adalah Terpenoid dan vitamin A yang merupakan antioksidan larut dalam minyak, sehingga dapat digunakan untuk mengabsorbsi radikal bebas yang terdapat dalam minyak (Kandari dkk, 2015).

Sedangkan antioksidan yang dimiliki oleh ampas nanas yaitu senyawa polifenol Polifenol merupakan senyawa turunan fenol yang mempunyai aktivitas sebagai antioksidan. Fungsi polifenol sebagai penangkap radikal bebas dari ion-ion logam yang rusak. Flavonoid dan asam fenolik berfungsi sebagai pemakan radikal bebas (Lingga, 2012).

Perbedaan jenis antioksidan pada belimbing wuluh dan ampas nanas akan membedakan kemampuan antioksidasasinya terhadap radikal bebas dalam minyak. Terpenoid dan Polifenol memiliki mekanisme antioksidasi yang berbeda. Kemampuan antioksidan terpenoid dengan cara mengabsorbsi radikal bebas dalam minyak, sedangkan polifenol memiliki mekanisme anti oksidan dengan cara memakan radikal bebas dari ion-ion logam yang rusak.

Pada penelitian ini, konsentrasi efektif belimbing wuluh lebih tinggi dibandingkan dengan konsentrasi ampas nanas. Perbedaan konsentasi ini pun memberikan pengaruh terhadap 
komposisi kandungan zat-zat antioksidan didalam kedua bahan, sehingga menimbulkan perbedaan daya antioksidannya. Perbedaan ini ditunjukkan dengan nilai rerata pada ketiga parameter dari kedua perlakuan.

Nilai rerata bilangan asam dan peroksida pada perlakuan dengan belimbing wuluh lebih rendah dibandingkan dengan ampas nanas. Hal ini mengandung makna bahwa jumlah asam lemak bebas dan radikal bebas yang diserap oleh belimbing wuluh lebih banyak dibandingkan dengan ampas nanas. Sedangkan absorbansi zat warna minyak pad belimbing wuluh lebih kecil dibandingakan dengan ampas nanas. Hal ini mengandung makna bahwa intensitas warna pada minyak yang diperalakukan dengan belimbing wuluh lebih cerah atau terang dibandingkan dengan. Hal ini menunjukkan bahwa belimbing wuluh mampu menyerap warna coklat pada minyak akibat proses osidasi, hidrolisis dan polimerasi lebih bnayak dibandingkan dengan ampas nanas. Dengan uraian ini belimbing wuluh lebih efektif seabgai antioksidan alami pada minyak.

Namun berdasarkan konsentrasi, belimbing wuluh membutuhkan konsentrasi lebih tinggi dibandingkan dengan ampas nanas. Hal bermakna bahwa jumlah belimbing wuluh yang dibutuhan lebih banyak untuk menghasilkan daya antioksidan yang efektif. Sementara pada ampas nanas walaupun dengan konsentrasi yang kecil sudah menunjukkan kemampuan anti oksidan yang signifikan. Dengan demikian, berdasarkan hasil penelitian ini dapat direkomendasikan bahwa penggunaan belimbung wuluh dengan konsneyrasi $3 \%$ sudah efektif untuk mempertahankan kualitas minyak goreng. Sedangan penggunaan ampas nanas lebih efektif jika konsentrasinya lebih tinggi lagi.

\section{KESIMPULAN}

Berdasarkan hasil penelitian ini dapat disimpulkan bahwa ada perbedaan daya nati oksidan yang diukur sebagai bilangan asam, bilangan peroksidan dan absorbansi warna antara belimbing wuluh dan ampas nanas.

\section{DAFTAR PUSTAKA}

Aminah, S. 2010. Bilangan Peroksida Minyak Goreng Curah dan SifatOrganoleptik Tempe padaPengulangan Penggorengan Universitas Muhammadiyah Semarang. Jurnal Pangan dan Gizi Vol. 01 No. 01.

Khasiat Belimbing Wuluh (Averrhoa bilimbi. L) terhadap Penyembuhan Acne Vulgaris. Fakultas Kedokteran. Universitas Lampung. Majority Volume 5 Nomor 1 : 76-80.

Badan Standarisasi Nasional. 2013. Standar Nasional Indonesia Minyak Goreng. SNI 3741: 2013 ICS 67.200.10. Hlm 1. 
Bera dalam Ayucitra, A. 2011. Potensi Senyawa Fenolik Bahan Alam Sebagai Antioksidan Alami Minyak Goreng Nabati. Universitas Katolik Widya Mandala Surabaya. Jurnal Widya Teknik. 10(I) hlm 1 - 10 .

Dewintasari, N.I. 2018. Karakterisasi Absorbansi Minyak Goreng Mengandung Plastik Menggunakan Spektrofotometer UV-Vis. Universitas Jember. $\mathrm{Hlm}$ 4-6.

Dhyanaputi, S.A.G.I, et all. 2017. Perbedaan Bilangan Peroksida Pada Minyak Jelantah Setelah Penambahan Bubuk Kulit Manggis (Garcinia mangostana Linn). Poltekkes Denpasar. Jurnal Skala Husada Volume 14 Nomor 1 April 2017 : 34 - 43.

Haris, M. 2011. Penentuan Kadar Flavonoid Total Dan Aktifitas Antioksidan Dari Daun Dewa (Gynura pseudochina [Lour] DC) Dengan Spektrofotometer Uv Visibel. Skripsi Sarjana Farmasi. Universitas Andalas Padang. Hlm 2.

Hertanto, B. 2012. Penggunaan Belimbing Wuluh untuk Menghambat Oksidasi dan Mempertahankan Mutu Organoleptik pada Dendeng Febriani, L.I., Belimbing Wuluh Terhadap Kualitas Minyak Curah. 2019. Sapi Selama Penyimpanan. Skripsi Departemen Ilmu Produksi dan Teknologi Peternakan. Fakultas Peternakan. Institut Pertanian Bogor. Hlm 3-5.
Kandari, A. 2015. Pengaruh Konsentrasi Dan Lama Pencampuran Sari Belimbing Wuluh (Averrhoa bilimbi L.) Terhadap Perubahan Mutu Minyak Jelantah Dari Pedagang Gorengan. Skripsi S1 Pendidikan Biologi. Fakultas Keguruan Dan Ilmu Pendidikan. Universitas Muhammadiyah Malang. SP-020-7 : 454-461.

Nainggolan, B, et all. 2016. Uji Kelayakan Minyak Goreng Curah dan Kemasan Yang Digunakan Menggoreng Secara Berulang. Fakultas MIPA. Universitas Negeri Medan. Jurnal Pendidikan Kimia, Vol.8, No.1, 45-57.

Nurhasnawati, H. 2015. Penetapan Kadar Asam Lemak Bebas dan Bilangan Peroksida Pada Minyak Goreng Yang Digunakan Pedagan Gorengan Di Jl. A.W Sjahranie Samarinda. Akademi Farmasi Samarinda. Jurnal Ilmiah Manuntung, 1(1), 25-30.

Przybylski dalam Paramitha Ariyani, A.R. 2012. Studi Kualitas Minyak Makanan Gorengan Pada Penggunaan Minyak Goreng Berulang. Skripsi Studi Ilmu Dan Teknologi Pangan. Fakultas Pertanian. Universitas Hasanudin Makassar. HIm 25-26.

Rorong, J, et all. 2008. Sintesis Metil Ester Asam Lemak Dari Minyak Kelapa Hasil Pemanasan. Jurusan Kimia. Fakultas Mipa. Unsrat Manado. Chem. Prog. Vol. 1, No. 1. 
Sani, P.L. 2017. Pemanfaatan Pemberian Ampas Nanas (Ananas comosus L. merr) Dalam Pengolahan Minyak Jelantah Menjadi Minyak Segar. Karya Tulis Ilmiah Program Studi D3 Analis Kesehatan. Fakultas Ilmu Kesehatan. Universitas Muhammadiyah Surabaya. Hlm 7 $18 ; 26 ; 37$.

Syabanu, A.A \& Cahyaratri, F. 2009. Pemanfaatan Asam Sitrat Sebagai Adsorben Dalam Upaya Peningkatan Kualitas Minyak Goreng Bekas Melalui Proses Adsorpsi. Universitas Diponegoro Semarang. Hlm 2.

Tim Kimia Amami. 2017. Modul Kimia Amami. Surabaya : Universitas Muhammadiyah Surabaya. Hlm 24-32.

Zainal, SP. 2016. Kementerian Ristek Dan Dikti Universitas Andalas Fakultas Matematika Ilmu Pengetahuan Alam Jurusan Biologi. Laboratorium Riset Fisiologi Tumbuhan. Padang. Hlm 15. 